\title{
Drivers of Wetland Conversion in the Tropical Environment
}

\author{
Benjamin Oluwafemi Adeleke
}

Department of Geography, Obafemi Awolowo University, Ile-Ife, Nigeria

\begin{abstract}
The study identified factors responsible for wetland dynamics and negative marks produced on the environment in the area. It equally suggested efforts aimed at reducing effects of the factors on the environment. The study incorporated both meta-analysis of case studies and questionnaires distribution and administration to the respondents who are mainly members of the Fadama User Group (FUG). The results showed changes in rainfall intensity as the major factor responsible for wetland loss; followed by settlement developments and loss of soil water due to river drainage. The results further revealed the effects of the factors to include siltation of drainages, destruction of ecosystem and loss of wetness, and emergent of heavy flooding. The study concluded by suggesting efforts aimed at reducing the influence of the factors on the environment.
\end{abstract}

Keywords: Environment, Meta-analysis, siltation, Water loss, Wetland dynamics

\section{INTRODUCTION}

Wetland occupies six percent of the world's land surface but it's among the most important and threatened ecosystems in the world IPCC (1996). Also about one percent of Africa's total surface area is wetland excluding coral reefs and some of the smaller seasonal wetlands (Kabii 1996). However, in Nigeria wetlands cover an extensive area $(13,000 \mathrm{~km} 2)$ and support a wide range of economic activities (NEST 1991). Each wetland is composed of a number of physical, biological and chemical components such as soil, water, plants and animal species, and nutrients which are of direct benefit to mankind (Tejuoso 2006). Wetlands play a number of roles in the environment, principally water purification, flood control, and shoreline stability. Wetlands are also considered as the most biologically diverse of all ecosystems,

Correspondence Author Benjamin Oluwafemi, ADELEKE, Department of Geography, Obafemi Awolowo University, IleIfe, Nigeria, Email : adelekeoluwafemi.ao@gmail.com serving as home to a wide range of plant and animal life (UNEP, 2012). It is an important source of water and nutrients necessary for biological productivity and sheer survival of the people (Thompson, 1996). And an exclusive source of natural resources upon which many rural African economies depend. Sustainable management of wetlands is therefore critical to the long-term health, safety and welfare of many African communities (Schuijt, 2002).

However, in spite of all the goods provided by wetlands, they are consistently assaulted globally, their loss and degradation occur worldwide, sometimes at extremely high rates (Moser et al., 1998). According to the findings of the World Resources Institute (2000) half of the world's wetlands have been lost during the twentieth century from land converted to agriculture and urban use. A review of 344 Ramsar sites showed that $84 \%$ were either threatened or experiencing ecological changes mostly from drainage, pollution and siltation (Kabii, 1996). Nigeria is not immune from this threat as one of its most important wetlands, the 
Hadejia-Nguru Wetlands in Jigawa and Yobe States have shrunk by as much as two-thirds in the past 30-40 years because of diversions from dams, irrigation developments and drought. Fisheries, farming and wildlife are all impacted by these hydrological changes (Idris, 2008). As people increasingly reclaim wetlands or distort the ecosystem balance, coupled with population increase, such problems are bound to worsen as they may not be aware of the effect of their activities on the agro-ecological values of the wetlands (Ekanade, 2011). However, a direct consequence of unabated utilization and conversion of wetlands is the rising flood incidences being experienced in our major cities and wetlands reclamation agricultural concentration zones.

\section{METHODOLOGY}

The dominant feature of the area is the Ogun River which flows in a generally north to south direction. Significant portions are drained by a number of major and minor rivers such as

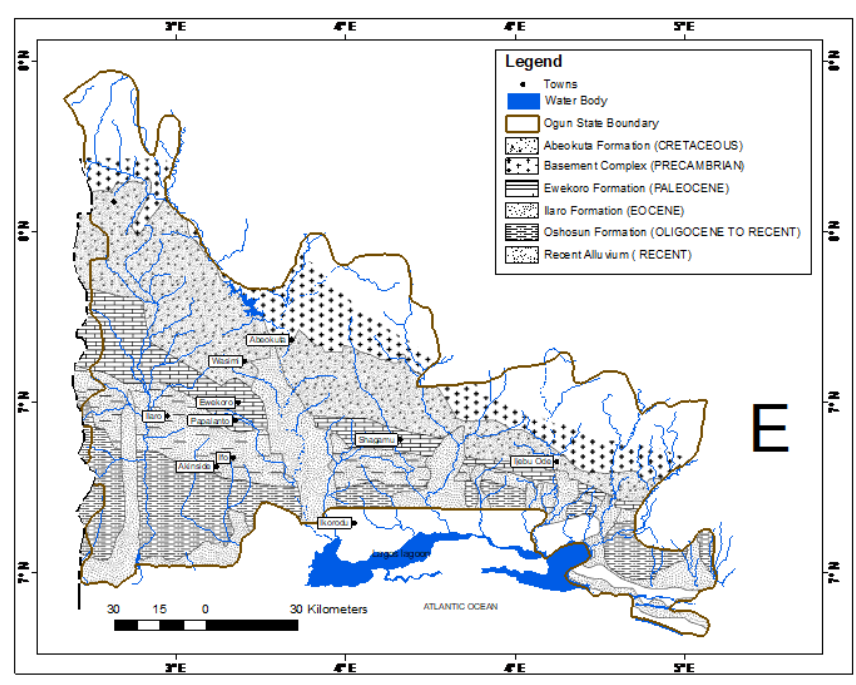

Figure 1: Drainage map of Ogun State

Ona-Ibu River in the south-east, the Osun in the east, Yewa in the west and Ewekoro and Adiyan Rivers in the south-west to form a dendritic drainage network and they flow throughout the year (Figure 1). Detailed site and soil descriptions of Ogun River Basin have been given by Adeleke (2017).

Two sources of data were used to meet the objective of this study. The first was the collection of data via existing documents and records in journals and other sources including meta-analysis of case studies in land changes (Asselen et al., 2013). The second source of data collection was through field survey. This was done by the administration of questionnaires and oral interviewing members of the Fadama Users Group (FUG) in the study area. Systematic random sampling technique was used to select respondents among the FUG. It was estimated that there are about 1,000 members of the FUG out of the 2,000 wetland users in the area (Olarewaju et al., 2011). Hence, 100 copies of structured questionnaires were randomly administered and distributed in the area. Simple percentage was used to summarize and organize questionnaire and interview responses. The questionnaires sought to gather information on the factors responsible for wetlands dynamics, soil fertility decline, and resultant effects of these factors on the environment in the locality.

\section{RESULTS AND DISCUSSION}

\section{Factors promoting wetland dynamics in the study area}

Table 1 enumerated various factors responsible for the loss of wetlands in the locality as posited by the respondents interviewed; the listing however, does not indicate which factor creates more damaging effects than the others. Most often the effects produced by forces of change on wetlands are borne out of complex interactions among factors responsible for such changes (Hunter, 2000). In the study area a number of factors were 
discovered during the ground truthing exercises, analysis of administered questionnaires and consultation of existing literatures. The factors included; changes in rainfall intensity and soil hydrology due to climate change, reduction in water body as a result of river/soil drainage, forested wetlands removal for farming, settlements/urban related developments and influx of migrants from neighboring villages and others. From the

Table 1. Factors/Forces Responsible for Wetland Dynamics

\begin{tabular}{lc}
\hline Forces of Change & Frequency/ Percentage \\
\hline Changes in rainfall intensity due to climate change & 44 \\
Reduction in water body due to river/soil drainage & 21 \\
Forested wetlands removal due to farming & 10 \\
Settlements/urban related developments & 22 \\
Influx of migrants from neighbouring villages & 3 \\
\hline Total & 100 \\
\hline
\end{tabular}

Table $44 \%$ of respondents attributed the dynamics in wetlands to changes in the intensity of rainfall as a result of much talked about climate change the world over (Jon Kusler, 2005). The climate change according to Barros and Albernaz, (2013) will affect tropical regions mostly due to changes in temperature and rainfall patterns. There are however, divergent results among scholars on the influence of rainfall intensities and distribution regime on the wetlands (Marengo, 2007; Marengo et al., 2009a, b). In Amazon, for example, some models derived from global models compiled by the IPCC indicated that the loss of wetlands was due to drastic reductions in precipitation, whereas others predict an increase (Barros and Albernaz, 2013).

Therefore, the environments of tropical wetlands are considered highly vulnerable to climate changes and might be affected in four different ways: by changes in the hydrological regime; changes in precipitation patterns; local changes in temperature/humidity and subsequently in patterns of evapotranspiration and increases in the frequency of extreme climate events (Murdiyarso et al., 2012). Added to these, the coastal wetlands, such as mangroves, might also be influenced by the rising of sea levels (Mitsch et al., 2010). Further, $22 \%$ of the respondents adduced the major factor to settlements/urban land related developments. The research findings cannot agree less with this factor as one of the major influencers of changes in the locality, because there seem to be influx of people from Abeokuta the state capital into the area. Most importantly situation of two major government institutions in the axis; The Moshood Abiola Polytechnic located at the outskirt of the town on the road to the area and the new Federal Prison in Oba village a major settlement in the area. As a result of which large parcel of forested lands hitherto dedicated to farming and other primary activities were encroached into to meet the accommodations need of staff and students of the institutions. The location of these institutions as permanent urban structures/influence in the area remains a major developmental challenge exerting great pressure on social, economic and environmental sustainability of the rural areas (Pickett et al., 2001). Also, Cohen (2004) was of the view that in developing countries, urbanization is associated with natural population growth, 
rural-urban migration, convergence in rural and urban lifestyles, and the economic and political processes associated with globalization.

Though urban areas currently account for about $3 \%$ of the earth's surface, the ecological footprint associated with urban expansion has important environmental consequences especially on wetland ecosystems (Ajibola et al, 2012). Relating to the influence of urban growth on wetlands loss is reduction in water body due to river/soil drainage and influx of migrants from neighbouring villages into the area to engage in wetland farming. Still from Table 1, $21 \%$ and $3 \%$ of the respondents respectively advanced the influence of reduction in water body due to river/soil drainage and influx of people all for the purpose of engaging in wetland farming. The effects of reduction in water body as a result of drainage for agriculture and other purposes are serious both in the short and long term as it has been predicted. In a short period of time, some species of freshwater aquatic biota will not be able to survive and reproduce under the new hydrological conditions and emergent increased salinity (Nielsen and Brock, 2009). This conforms to the observation of loss of wetland structures of the vegetation during the ground truthing exercise in the study area as many of the biota could not withstand and reproduce effectively in the altered ecosystem. The influence of influx of people into the area for wetland farming (3\%) as posited by the respondent was to say the least underestimated as population is known to influence land use in a number of ways more than any other factors put together (Fanan et al., 2011). The growth of most Nigerian cities such as Kano, Ibadan, Enugu, Port-Harcourt, Kaduna, Calabar, and others are attributed mainly to rural-urban migration (Aliyu and Amadu 2017). This urbanization process has outpaced the existing urban management system. Even 1996 World Bank reports on Nigeria indicated that the growth rate of urban areas increased from $20 \%$ in 1970 to $33 \%$ in 1993 and projected that by the year 2025, estimated $75 \%$ of Nigeria's population of about 245 million persons would live in towns and cities (Ajibola etal. 2012).

\section{Influence of Wetland Dynamic on the Environments}

Table 2 summarized the visible marks produced in the environment as expressed by respondents who are mainly members of FUG due to negative effects of wetland loss in the area. About $20 \%$ of the respondents confirmed that there was emergent of annual destructive flood incidences in the area due to loss of wetlands which would have served as buffer and flood abatement/control (Odine etal. 2011). The annual flooding has resulted in the loss of several farmland and crops to floods in the area on many occasions and constitute a serious economic and man hour loss. The evidence of flood is equally glaring in the forms of erosion channels and gullies in the area, most especially on farmlands that are closer to the bank of rivers and other water bodies. The primary cause of wetland loss in Lagos Metropolis has been explained by Adeleke (2017). Loss of water in the drainages is equally glaring in most of the rivers and water bodies in the area as expressed by $26 \%$ of the respondents; siltation of drainages was rampant and noticeable in the area which according to $28 \%$ of the respondents, most of the shallow water bodies in the area was once deep and full with water. Such disturbances as draining for agriculture and sand filling for developmental purposes like road constructions, which directly change the structure of wetlands, can be so severe that the wetland was destroyed. Filling or 
Table 2. Features of Wetland Dynamics

\begin{tabular}{|c|c|}
\hline Features of wetland dynamics & Frequency/Percentage \\
\hline Emergent of heavy flooding in the area & 20 \\
\hline Loss of water & 26 \\
\hline Siltation of drainages & 28 \\
\hline Destruction of wetland ecosystem & 26 \\
\hline Total & 100 \\
\hline $\begin{array}{l}\text { draining a wetland can so alter the water regime } \\
\text { that the land can no longer support the wetland } \\
\text { vegetation and maintain hydric soils which may } \\
\text { resulted in the loss of wetlands and most if not } \\
\text { all its functions (Ajibola et al., 2012). Another } \\
\text { feature of wetlands destruction produced by the } \\
\text { forces of change was the destruction of wetland } \\
\text { ecosystem for farming through forests removal, } \\
\text { river drainages, and application of chemicals. } \\
\text { This singular feature has led to the loss of } \\
\text { wetland related life forms of both fauna and } \\
\text { flora according to } 26 \% \text { of the respondents, } \\
\text { which are now very scarce in the area unlike in } \\
\text { the past (Andrew Ker 1995). According to } \\
\text { Ehrenfeld and Schneider (1991) wetlands } \\
\text { commonly occur in human-dominated } \\
\text { landscapes such as agricultural and urban } \\
\text { regions. Or put correctly there is always } \\
\text { population concentration in wetlands area for } \\
\text { agricultural related purposes and in the event of } \\
\text { Table } 3 \text {. Wetlands Suggested Res }\end{array}$ & $\begin{array}{l}\text { Source: Adeleke } 2017 \\
\text { land scarcity for further developments, wetlands } \\
\text { area provides the ready alternative for filling. } \\
\text { Studies have, however established that negative } \\
\text { effect on wetland species and ecosystem } \\
\text { functioning can be expected in such areas due to } \\
\text { human activities (Ehrenfeld and Schneider, } \\
\text { 1991; Morris, 1991). } \\
\text { Suggestions for Wetlands Restoration in the } \\
\text { Study Area } \\
\text { Table } 3 \text {, however proffered some restoration } \\
\text { efforts as suggested by the respondents to } \\
\text { include preservation of uncultivated forested } \\
\text { wetlands ( } 57 \% \text { ), } 22 \% \text { suggested improvement in } \\
\text { farming systems which to them will prevent } \\
\text { incursion into more uncultivated forested lands. } \\
\text { while } 14 \% \text { of the respondent suggested } \\
\text { deliberate re-forestation of already destroyed } \\
\text { forests so as to bring back the natural wetland } \\
\text { forest earlier removed from the area. } \\
\text { oration Efforts by the Inhabitants }\end{array}$ \\
\hline Restoration Efforts & Frequency/ Percentage \\
\hline Deliberate re-forestation & 14 \\
\hline De-siltation of river channels & 7 \\
\hline Preservation of uncultivated forested wetlands & 57 \\
\hline Improved farming systems & 22 \\
\hline Total & 100 \\
\hline
\end{tabular}




\section{CONCLUSONS}

The study identified factors bringing about changes in the wetland coverage of the study area and demonstrates the influence of these factors on the area through the negative marks produced on the environment. The study further made a number of suggestions aiming at ameliorating the effects of the factors on the environment so as to ensure the preservation and sustainable use of wetlands to continue the provision of wetlands goods and services to mankind.

\section{REFERENCES}

Adeleke, B.O. (2017). Human population growth as proximate cause of wetland dynamics. International Journal of Human Capital in Urban Management. 2(4): 259266.

Adeleke, B.O., (2017a). Assessment of wetland dynamics and soil quality in Lower Ogun River Basin of Southwestern Nigeria. Unpublished Ph.D. Dissertation, Department of Geography, Obafemi Awolowo University, Ile-Ife, Nigeria.

Ajibola, M. O, Adewale, B. A and Ijasan, K. C. (2012) Effects of Urbanization on Lagos Wetlands, International Journal of Business and Social Science 3(17): 310318.

https://ijbssnet.com/journal/index/1534

Aliyu, A and Amadu, L (2017). Urbanization, cities and health: the challenges to NigeriaA review. Wolters Kluvert/Medknow Publications Ann Afr Med. 16(4): 149-158. https://www.ncbi.nlm.nih.gov/pmc/articles/ $\underline{\text { PMC5676403/ }}$
Andrew Ker (1995). Farming systems of the African Savanna: A continent in crisis. IDRC Nairobi, Kenya. 1-176 https://www.idrc.ca/en/book/farmingsystems-african-savanna-continent-crisis

Asselen, S.V, Verburg, P.H, Vermaat, J.E, Janse, J.H (2013) Drivers of Wetland Conversion: A Global Meta-Analysis. PLOS ONE 8(11): 1-13. https://www.ncbi.nih.gov/pubmed/2428258 $\underline{0}$

Barros, D.F. and Albernaz, A.L.M. (2014). Possible impacts of climate change on wetlands and its biota in the

Brazilian Amazon. Brazilian Journals of Biology. $\quad 74(4)$ : 810-820. http://dx.doi.org/10.1590/1519-6984.04013

Cohen, B. (2004) Urban Growth in Developing Countries: A Review of Current Trends and a Caution Regarding Existing Forecasts. World Development 32(1): 23-51. http://www.sciencedirect.com/science/articl e/pii/s0305750X03001967

Ehrenfeld, J.G. and Schneider, J.P. (1991). Chamaecyparis Thyoides Wetlands and Suburbanization: Effects on Hydrology, Water Quality and Plant Community Composition. - Journal of Applied Ecology 28: 467-490. In Ajibola, M. O, Adewale, B. A and Ijasan, K. C. 2012 Effects of Urbanisation on Lagos Wetlands, International Journal of Business and Social Science 3(17): 310-318. https://ijbssnet.com/journal/index/1534

Ekanade, R.O (1997). Hill-Slope AgroEcosystem and Their Implications on Environmental System in Rural Southwestern Nigeria. Agriculture, Ecosystem and Environment, 61:92-102. In Salami, A.T and Orimoogunje, O.O.I 
(2011). Environmental Research and Challenges of Sustainable Development in Nigeria, Obafemi Awolowo University Press, Ile-Ife Nigeria. 31-62. https://searchworks.stanford.edu.view/9585 $\underline{415}$

Ekanade, R.O (2011). Biogeographical Development and Environmental Issues in Nigeria. In Salami, A.T and Orimoogunje, O.O.I (2011). Environmental Research and Challenges of Sustainable Development in Nigeria Obafemi Awolowo University Press, Ile-Ife Nigeria. 31-62. https://searchworks.stanford.edu.view/9585 $\underline{415}$

Fanan, U., Kwabe I.D and Ifatimehin O.O (2011). Urban expansion and vegetal cover loss in and around Nigeria's Federal Capital City, Journal of Ecology and the Natural Environment. Academic Journals. 3(1): $\quad 1-10$

http://www.academicjournals.org/jene

Hunter, L. M. (2000). The environmental implications of population dynamics. Population matters. A RAND Program of Policy-Relevant Research Communication. 1-123 (123 pages) http://www.rand.org/ Idris, M. (2008). "Damming Nigeria's wetlands People: Communities Work Together to Restore Lives and Livelihoods" World Rivers Review: Legacy Issue. 239-244. https://wwww.internationalrivers.org/resou rces/damming-nigeria-s-wetlands-peoplecommunities-work-together-to-restorelives-and-livellhoods

IPCC. (1996). Climate Change 1995, The Science of Climate Change. Houghton, J,T., Meira Filho, L.G., Callander, B.A., Harris, N., Kattenberg, A and Maskell, A. p ISSN: 2354-5844

e ISSN: 2477-5223

(Eds). Cambridge University Press, UK. Pp. 572.

Jon Kusler (2005). Wetland, Climate Change and Carbon Sequestering. Association of State Wetland Managers. Inc 1-29. http://www.aswm.org/pdf_lib/11_carbon_6 26_06.pdf

Kabii, T. (1996). An Overview of African Wetlands. Ramsar Convention Bureau, Switzerland. 1-6. http://www.oceandocs.org/bitstream/handle /1834/457/Africa

Marengo, J.A. 2007. Mudanças climáticas globais e seus efeitos sobre a biodiversidade: caracterização do clima atual e definição das alterações climáticas para o território brasileiro ao longo do século XXI. 2nd ed. Brasília: Ministério do Meio Ambiente. 212 p. In Barros, D.F. and Albernaz, A.L.M. (2014). Possible impacts of climate change on wetlands and its biota in the Brazilian Amazon. Brazilian Journals of Biology. 74(4): 810-820. http://dx.doi.org/10.1590/1519-6984.04013 Marengo, J.A. Ambrizzi, T., Rocha, R.P., Alves, L.M., Cuadra, S.V., Valverde, M.C., Torres, R.R., Santos, D.C. and Ferraz, S.E.T., 2009a. Future change of climate in South America in the late twenty-first century: intercomparison of scenarios from three regional climate models. Climate Dynamics. 35:1089-1113. https://www.researchgate.net/publication/3 $\underline{13615817}$

Marengo, J.A., Jones, R., Alves, L.M. and Valverde, C.M., 2009b. Future change of temperature and precipitation extremes in South America as derived from the PRECIS regional climate modeling system. International Journal of Climatology. 30: 1- 
15.

http://onlinelibrary.wiley.com/doi/10.1002/ joc. $1863 / \mathrm{pdf}$

Mitsch, W.J. Nahlik, A. Wolski, P. Bernal, B. Zhang, L.I. and Ramberg, L. (2010). Tropical wetlands: Seasonal hydrologic pulsing, carbon sequestration, and methane emissions. Wetlands Ecology and Management. $\quad$ 18(5): 573-586. http://dx.doi.org/10.1007/s11273-0099164-4.

Morris, J.T. (1991): Effects of Nitrogen Loading on Wetland Ecosystems with particular reference to Atmospheric Deposition. Annual Review of Ecology and Systematics 22: 257-279. https://doi.org/10.1146/annurev.es.22.1101 $\underline{91.001353}$

Moser M, Prentice C, and Frazier S (1998) A Global Overview of Wetland Loss and Degradation. ramsar.

http://www.ramsar.org/en/ramsar-newsarchives-2002-a-global-overviewof/main/ramsar/1-26-4587\%5E16905_4000_0

Murdiyarso, D., Kauffman, J.B., Warren, M., Pramova, E. and Hergoualc'h, K. (2012). Tropical wetlands for climate change adaptation and mitigation: Science and policy imperatives with special reference to Indonesia. CIFOR, Bogor, Indonesia. 91:168 (68 pages). www.cifor.org

National Population Commission (NPC), (2006). Federal Republic of Nigeria Official Gazette, Lagos. www.population.gov.ng

Nielsen D.L. and Brock M.A. (2009). Modified water regime and salinity as a consequence of climate change: prospects for wetlands of Southern Australia. Climatic Change.
95(3-4):

523-533.

https://link.springer.com/article/10.1007/s1 0584-009-9564-8

NEST (Nigerian Environmental Study/ Action Team) (1991). Nigeria's Threatened Environment: A National Profile. 1-288. http://www.nestinteractive.org/publications .php

https://www.ircwash.org/resources/nigerias -threatened-environment-national-profile

Odine A. T., Shittu A. M., Ayinde I. A. and Olubanjo O. O. (2011). Assessment of the Economic Value of Selected Wetlands in Southwest, Nigeria. Proceedings of the Environmental Management Conference, September 12 -15, 2011, Federal University of Agriculture, Abeokuta, Nigeria. 1: 86100.

http://www.unaab.edu.ng/attachments/volu $\underline{\text { me1.pdf }}$

Olarewaju T. O., Shittu A. M, Olubanjo O. O. and Dipeolu A. O. (2011) Perceived Benefits of Selected Wetlands in SouthWest Nigeria. Proceedings of the Environmental Management Conference, September 12 -15, 2011, Federal University of Agriculture, Abeokuta, Nigeria. 1: 155166.

http://www.unaab.edu.ng/attachments/volu $\underline{\text { me1.pdf }}$

Pickett, S.T.A., Cadenasso, M.L., Grove, J.M., Nilon, C.H., Pouyat, R.V., Zipperer, W.C., Constanza, R., (2001) Urban Ecological Systems: Linking Terrestrial Ecological, Physical, and Socioeconomic Components of Metropolitan Areas. Annual Review of Ecology and Systematics 32: 127-157. http://www.ecologia.ufrgs.br/adrimelo/ecossistemas/2001_urban_ecologi cal_systems_pdf 
http://www.annualreviews.org/doi/abs/10.1 146/annurev.ecolsys.32.081501.114012

Schuijt, K.D. (2002). Land and Water Use of Wetlands in Africa Economic Values of African Wetlands; International Institute for Applied System Analysis Schlossplatz 1 A-2361 Laxenburg Austria. 1-46. http://pure.iiasa.ac.at/6723/1/IR-02-063.pdf

Tejuoso, O. J. (2006): "Wetland uses/dynamics for agricultural purposes and its health implications in lower Ogun river basin, Lagos, Nigeria" A technical report submitted to International Development Research Centre (IDRC) (Ecosystem Approach to Human Health Team). 20-22. https://www.researchgate.net/publication/2 77170398

Thompson, J.R., (1996). Africa's Floodplains: a Hydrological Overview. In Schuyt, K.D (2005). Economic consequences of wetland degradation for local population in Africa. Ecological Economics 53(2): 177-190. $\underline{\text { www.sciencedirect.com }}$ e ISSN: 2477-5223

Titus, J.G. Wedge, R. Psuty, N. Fancher, J. (1989) Changing Climate and the Coast Volume 2: Western Africa, the Americas, the Mediterranean Basin, and the rest of Europe: Report of the Intergovernmental Panel on Climate Change; From the Miami conference on adaptive responses to Sea Level Rise and other impacts of Global Climate Change. https://nepis.epa.gov//Exel/ZyNET.exe/600 000EN.TXT?

UNEP (United Nation Environmental Programme) (2012). The economics of ecosystems and biodiversity for water and wetlands. Convention on biological diversity. $11^{\text {th }}$ meeting, Hyderabad, India, 8-19 October, $2012 . \quad 1-119$. http://www.cbd.int/doc/meetings/co11/info rmation/cop-11-inf-22-en.pdf.

World Resources Institute, (2000, 2002). Pilot Analysis of Global EcosystemsFreshwater. World Resources Institute. Washington. DC. Www.wri.org 